\title{
Time-Varying and Asymmetric Relationship between Energy Use and Macroeconomic Activity
}

Ayşen SÍVRIKAYA (https://orcid.org/0000-0003-2199-3593), Department of Economics, Hacettepe University, Turkey; e-mail: aysens@hacettepe.edu.tr

Mübariz HASANOV (https://orcid.org/0000-0003-0216-9531), Department of Economics and Finance, Istanbul Okan University, Turkey; e-mail: muhariz.hasanov@okan.edu.tr

\section{Enerji Kullanımı ile Makroekonomik Aktivite Arasındaki Zamanla Değişen ve Asimetrik İlişki}

\begin{abstract}
In this paper, we analyze the dynamic interactions among energy use, output, capital stock and employment for the USA. Our results suggest that these interactions are time-varying and show asymmetries in terms of the one variable's responses of big versus small and positive versus negative shocks to another variable. In particular, we find that negative energy shocks have greater impact on macroeconomic variables than positive shocks. Furthermore, small energy shocks have greater effects than big shocks. Our results also suggest that the shocks to production factors reduce energy use, implying that energy and the other factors of production are substitutes rather than compliments. These results have clear policy implications. Namely, aggressive energy saving policies might be more politically viable. In addition, the policies promoting more efficient and energy-saving capital and production technologies could help reducing energy use.
\end{abstract}

Keywords

JEL Classification Codes :
Asymmetry, Employment, Energy Demand, Structural Change, Output Growth.

Öz

$\mathrm{Bu}$ çalışmada, enerji kullanımı, çıktı, sermaye stoku ve istihdam arasındaki dinamik etkileşimler $\mathrm{ABD}$ verileri kullanılarak analiz edilmiştir. $\mathrm{Bu}$ çalışmadan elde edilen bulgular, bu etkileşimlerin zamanla değiştiğini ve bir değişkenin başka bir değişkende gerçekleşen büyük ve küçük şoklara verdiği tepkilerin asimetrik olduğunu göstermektedir. Benzer şekilde, bir değişkene vuran pozitif ve negatif şokların diğer değişkenler üzerindeki etkileri birbirinden farklıdır. Daha özel olarak bu çalışmada, makroekonomik değişkenlerin negatif enerji şoklarına pozitif şoklara göre daha fazla tepki verdiği bulgusuna ulaşılmıştır. Ayrıca, çalışma sonuçlarına göre, küçük enerji şoklarının büyük şoklara göre makroekonomik değişkenler üzerindeki etkileri daha büyüktür. Bunlara ek olarak, üretim faktörlerine yönelik şoklar enerji kullanımını azaltmaktadır. Bu bulgu, enerji ve diğer üretim faktörlerinin tamamlayıcı olmak yerine ikame olduğuna işaret etmektedir. Bu çalışmadan elde edilen bulguların çok açık politika sonuçları bulunmaktadır. Çalışma sonuçlarına göre, enerji tasarrufunu destekleyen politika uygulamaları ekonomik büyümeye engel olmamaktadır. Ayrıca, daha verimli ve enerji tasarrufu sağlayan sermaye ve üretim teknolojilerini teşvik eden politikalar, enerji kullanımını azaltmaya yardımcı olabilmektedir.

\section{Anahtar Sözcükler $\quad$ : Asimetri, İstihdam, Enerji Talebi, Yapısal Değişiklik, Çıktı} Büyümesi. 


\section{Introduction}

Design and implementation of politically viable and sustainable energy policies require clear understanding of causal relationship among energy use and macroeconomic variables. Therefore, this issue has been in the center of interest of both economists and policymakers. The recent increase in concerns about the energy security and the environmental issues gave a new impetus to the research on this issue.

Since the seminal work of Kraft and Kraft (1978), a growing body of literature has been devoted to examination of the relationship between energy use and economic growth. Yet, there is neither a consensus on the existence of the relationship nor on the direction of causality between them ${ }^{1}$. In particular, there are four competing views in the literature: neutrality hypothesis, growth hypothesis, conversation hypothesis, and feedback hypothesis. According to the "neutrality hypothesis", there is no relationship between energy use and output, and hence, energy saving policies will not affect output and employment adversely (Yu \& Jin, 1992). Supporters of the "growth hypothesis" claim that energy is a complement to labor and capital in the production function, and therefore reducing energy use will hamper output (Stern, 2000; Oh \& Lee, 2004; Ghali \& El-Sakka, 2004; Beaudreau, 2005, Lee \& Chang, 2008). Proponents of the "conservation hypothesis" declare that output growth positively affects energy use, but not vice-versa. Therefore, the implications of the energy conserving policies do not have to have negative effects on employment and output (Lee \& Chang, 2008; Apergis \& Payne, 2009). Finally, the "feedback hypothesis" states that the causality relationship between energy use and output growth is bi-directional. Hence, reducing energy use may negatively impact output growth.

In this paper, we examine the relationship among energy use and macroeconomic variables in the case of the USA. The existing empirical literature in the case of the USA has also produced inconclusive results ${ }^{2}$. For instance, in their pioneering study, Kraft and Kraft (1978), as well as Sari et al. (2008), Menyah and Wolde-Rufael (2015) find evidence in favor of conservation hypothesis, while Stern (1993, 2000), Bowden and Payne (2010), and Payne (2011) provide evidence for growth hypothesis. Gross (2012) argues that the results of the majority of the studies support the neutrality hypothesis (for example, Zachariadis, 2007; Payne, 2009).

The mixed results on the interrelationship among energy use and macroeconomic variables may be attributed to several factors, including use of different variables, econometric methods, time periods and frequency of the data (see, for example, Ozturk, 2010; Smyth \& Narayan 2015). However, nowadays economists generally accept that the interrelationship among economic variables might be inherently nonlinear as well as change 
over time (e.g., Granger \& Teräsvirta, 1993; Lin \& Teräsvirta, 1994; Bai \& Perron, 1998; Lundbergh et al., 2003), which also may explain why researchers find conflicting results for the same country.

Our aim in this paper is to re-examine the interrelationship among energy use and main macroeconomic variables in the case of the USA allowing both for structural changes and asymmetries in the dynamic interaction among the variables. From theoretical point of view, both structural changes and nonlinearities are plausible ${ }^{3}$. In fact, Hasanov and Telatar (2011) find that both structural breaks and nonlinearities may prevail in energy consumption of most countries. Therefore, empirical researchers must adopt appropriate modeling strategies to detect and deal with possible structural breaks and nonlinearities, if any. While researchers have examined either time-varying (e.g. Hooker, 1996; Aslan et al. 2014) or asymmetric (Hamilton, 2003; Rahman \& Serletis, 2010; Tiwari, 2014) relationship among energy and macroeconomic variables in the case of the USA, to the best of our knowledge, both time-varying and asymmetric features have not been examined yet. The purpose of this paper is to fill this gap in the empirical literature.

The main novelty of the paper is that we employ a unique econometric method that allows researchers to deal with both structural breaks and possible nonlinearities. We follow Hasanov et al. (2010), who generalized time-varying smooth transition regression (TV-STR) modeling approach of Lundbergh et al. (2003) to a multivariate framework. The TV-STR models have several advantages over competing structural break and nonlinear models. First, it allows for simultaneous nonlinearities and structural breaks in the interrelationship among variables whereas other structural break and nonlinear models exclude each other. For example, the structural break model of Bai and Perron (1998) deals with only structural breaks but not with possible asymmetries. Second, the TV-STR models allow choosing the most appropriate model for the data under analysis. In particular, the specification procedure of a TV-STR model requires use of a battery of statistical tests to determine whether only a break model or only a nonlinear model or a model allowing both structural breaks and nonlinearities is appropriate for the data used. Third, this modeling approach allows choosing appropriate transition functions that govern nonlinear dynamics and structural breaks. For example, after choosing the appropriate regime-switching variable, one may test whether nonlinear dynamics depend on the sign or on the size of this regime-switching variable. Similarly, if a structural break is determined, one may test whether there is a single or multiple break. Fourth, both structural breaks and regime switches are allowed to be gradual, which is theoretically more appealing than instantaneous change models such as threshold or Markov regime-switching models. Additionally, STR models nest abrupt breaks or transitions as special cases. Finally, the TV-STR modeling approach allows choosing appropriate regime-switching variables endogenously, and break dates and/or threshold

3 For a thorough discussion of plausible theoretical causes of structural breaks and nonlinearities, see, for example, van Dijk (1999). 
values are also estimated but not imposed as in other models. This allows determining the variable that causes nonlinearities in the interrelationship among variables. Thus, compared to other nonlinear approaches, the methodology in this study permits tracing wider aspects of dynamic interactions among energy and macroeconomic variables.

Taking account of these merits of the TV-STR models, we choose this modeling approach to examine the relationship among energy use, output, capital stock and labor, building on a standard production function following Stern (1993, 2000). In fact, as Stern (2000) argues, "changes in energy use are frequently encountered by the substitution of other factors of production, resulting in an insignificant overall impact on output". If energy input complements or substitutes other production factors, changes in energy use will affect capital and/or labor, which in turn determine output level. In this case, even when there is no direct relationship between energy use and output, it will affect output through its indirect effects on other production factors (Jorgenson, 1984; Hall et al., 1986). Berndt and Wood (1979), Koetse et al. (2008), and Fiorito and van den Bergh (2011), among others, find evidence in favor of complementarity or weak substitutability between energy and capital by using aggregate production functions for OECD countries ${ }^{4}$. Therefore, in examining the energyoutput nexus, one must consider the effects of capital stock and labor use as well. In fact, Moroney (1992) argues that energy and capital were jointly substituted for labor in the USA. He also finds that the effects of energy use on growth changed after the 1973 energy shock $^{5}$. Furthermore, the failure to consider effects of other production factors may cause to "omitted variable bias", which questions the reliability of the results drawn from bi-variate models (e.g., Lutkepohl, 1982). Therefore, we use a multivariate model to examine the interrelationship among energy use and macroeconomic variables.

The rest of the paper is organized as follows. In section 2, we briefly describe the econometric methodology used in this paper. In Section 3, we present the estimation results. Dynamic interrelationships among the variables are investigated in Section 4. Section 5 provides clear policy implications and concludes.

\section{Econometric Methodology}

In this paper, we consider a four-variable production function in order to examine the relationship between energy use and macroeconomic activity. In particular, we consider the following neoclassical production function augmented with energy use (e.g., Stern 1993; 2000):

4 Bartleet and Gounder (2010), Zhixin and Xin (2011), Wang et al. (2011), among others, also use multivariate models to examine energy-output nexus.

5 Hooker (1996) present some evidence that the effects of oil prices have changed after the 1973 oil shock as well as that these effects are asymmetric. Carmona et al. (2017) also provide some evidence of asymmetric relationship among energy use and output. 


$$
Y_{t}=A K_{t}^{\alpha} L_{t}^{\beta} E_{t}^{\gamma}
$$

Here $Y_{t}, \mathrm{~K}_{t}, L_{t}$ and $E_{t}$ denote output, capital stock, employment and energy use at time $t$, while $\alpha, \beta$, and $\gamma$ represent the capital, labor and energy elasticity of output, respectively. Taking the logarithm of both sides of the equation, one gets a linear production function as in (2):

$$
y_{t}=c+\alpha k_{t}+\beta l_{t}+\gamma e_{t}
$$

where $c=\ln A$, and $y_{t}, k_{t}, l_{t}$ and $e_{t}$ denote the natural logarithms of output, capital stock, employment and energy use, respectively.

The basic econometric model used to analyze the relationship among these variables, is a four-variable smooth transition vector autoregressive (ST-VAR) model. Let $x_{t}=$ $\left(y_{t}, k_{t}, l_{t}, e_{t}\right)^{\prime}$ be a $(4 x 1)$ vector time series. The ST-VAR model can be written as follows (see, for example, Araç \& Hasanov, 2014):

$$
x_{t}=\Psi_{1,0}+\sum_{i=1}^{p} \Psi_{1, i} x_{t-i}+\left(\Psi_{2,0}+\sum_{i=1}^{p} \Psi_{2, i} x_{t-i}\right) * F\left(s_{t} ; \gamma, c\right)+\varepsilon_{t}
$$

Based on Equation (2), the benchmark linear model is a VAR model similar to the one used by Stern $(1993)$. Here $\Psi_{j, 0}, j=1,2$ are $(4 \times 1)$ vector of constants, $\Psi_{j, i}, j=$ $1,2, i=1,2, \ldots, p$ are $(4 \times 4)$ matrices of parameters, and $\varepsilon_{t}=\left(\varepsilon_{y t}, \varepsilon_{k t}, \varepsilon_{l t}, \varepsilon_{e t}\right)$ is a $(4 \times 1)$ vector of residuals with mean zero and $(4 \times 4)$ covariance matrix $\Sigma$. Two widely used choices of transition function $F\left(s_{t} ; \gamma, c\right)$ are the logistic function (4a) and the exponential function (4b) where $s_{t}$ is the transition variable. $\gamma$ is the slope parameter with $\gamma>0 . c$ is called the location parameter.

$$
\begin{aligned}
& F\left(s_{t} ; \gamma, c\right)=\frac{1}{\left(1+\exp \left\{-\gamma\left(s_{t}-c\right)\right\}\right)}, \gamma>0 \\
& F\left(s_{t} ; \gamma, c\right)=\left(1-\exp \left\{-\gamma\left(s_{t}-c\right)^{2}\right\}\right), \gamma>0
\end{aligned}
$$

The transition functions are continuous functions that are bounded between 0 and 1 . The extreme values of the transition function $F\left(s_{t} ; \gamma, c\right)=0$ and $F\left(s_{t} ; \gamma, c\right)=1$ generate two extreme regimes. However, the parameters of the model (3) change smoothly from $\Psi_{1, i}$ to $\Psi_{1, i}+\Psi_{2, i}$ as the value of the transition function $F\left(s_{t} ; \gamma, c\right)$ changes from the lower bound to the upper bound. In other words, although the STR models nest two extreme regimes, they allow for an infinite number of regimes as the parameters in the model are general functions of the state variable $s_{t}$.

This transition functions given in (4a) and (4b) yield the logistic STR (LTSR), and exponential STR (ESTR) models, respectively. The LSTR model is convenient for modelling different dynamics depending on the size of the transition variable. If, for example, a growth rate is selected as a transition variable, then the resultant LSTR model 
will describe a situation where recessionary and expansionary periods have rather different dynamics. In contrast, the transition between regimes will occur symmetrically for the ESTR model. Thus, ESTR model implies that recessionary and expansionary periods have similar dynamics, but dynamics differ according to the speed of growth (Teräsvirta \& Anderson, 1992).

If time trend $(t)$ is chosen as a transition variable $\left(s_{t}\right)$ in Equation $(4 \mathrm{a}-4 \mathrm{~b})$, then the resultant model will be time-varying VAR (TV-VAR) model. In this case, the slope parameter $\gamma$ will determine the speed of change, and reciprocal of $c$ will represents the (average) location of the parameter change (Lin \& Teräsvirta, 1994).

In order to specify an appropriate ST-VAR model, "specific-to-general" approach can be adopted. In the first step of this approach, an appropriate linear model is estimated and then linearity of the model is tested against smooth-transition type nonlinearity. However, under the null hypothesis of linearity, $\Psi_{2, i}, i=0,1,2, \ldots, p$ are unidentified nuisance parameters, which renders standard asymptotic inference invalid. Following Luukkonen et al. (1988), the presence of unidentified nuisance parameters problem can be circumvented by approximating the transition functions in (4) by a first-order Taylor expansion around the null hypothesis. The following auxiliary regression model is obtained by replacing the transition functions in (4) by their first-order Taylor expansion.

$$
x_{t}=\Phi_{1,0}+\sum_{i=1}^{p} \Phi_{1, i} x_{t-i}+\sum_{i=1}^{p} \Phi_{2, i} x_{t-i} s_{t}+\sum_{i=1}^{p} \Phi_{3, i} x_{t-i} s_{t}^{2}+\sum_{i=1}^{p} \Phi_{4, i} x_{t-i} s_{t}^{3}+e_{t}
$$

The vector $e_{t}$ consists of the original shocks $\varepsilon_{t}$ and the error arising from the Taylor approximation. In (5) it is assumed that the transition variable $s_{t}$ is one of the elements of $x_{t}$. If this is not the case, then additional regressors $\Phi_{5} s_{t}^{i}, i=1,2,3$ enter the auxiliary regression model (5). The parameters in (5), $\Phi_{j, i}, j=1,2 . .4, i=0,1,2, \ldots p$, are functions of the parameters $\Psi_{j, i}, j=1,2, i=0,1,2, \ldots p, \gamma$ and $c$ in the STR-VAR model in (3).

In (5), it is clear that $\Phi_{1, i}=\Psi_{1, i}$ and $\Phi_{2, i}=\Phi_{3, i}=\Phi_{4, i}=0$ if and only if $\gamma=0$ in (3). Therefore, the null hypothesis of linearity in the auxiliary regression model (5) is written as $H_{0}: \Phi_{2, i}=\Phi_{3, i}=\Phi_{4, i}=0$, which can be tested by a likelihood ratio (LR) test. The LR test statistic for linearity of a $m$ variable VAR model with $p$ lags is given by $L R=T\left\{\log \left|\boldsymbol{\Omega}_{\mathbf{0}}\right|-\log \left|\boldsymbol{\Omega}_{1}\right|\right\}$, which is asymptotically distributed $\chi^{2}\left(3 \mathrm{pm}^{2}\right)$ where $\boldsymbol{\Omega}_{\mathbf{0}}=\sum \hat{\mathbf{e}}_{\mathbf{t}} \hat{\mathbf{e}}_{\mathbf{t}}^{\prime} / T$ and $\boldsymbol{\Omega}_{1}=\sum \hat{\mathbf{e}}_{\mathbf{t}} \hat{\mathbf{e}}_{\mathbf{t}}^{\prime} / T$ are the estimated variance-covariance matrices of residuals from the restricted and the unrestricted regressions, respectively.

If the null hypothesis of linearity is not rejected against any alternatives, then one retains the linear VAR model. If the linearity test described above suggests that the appropriate model is a nonlinear ST-VAR model, then one may follow the procedure of Teräsvirta (1994) to decide which transition function is statistically more convenient. In particular, in order to choose appropriate transition function, Teräsvirta (1994) suggests testing following null hypotheses based on auxiliary regression model given in (5): 
$H_{30}: \Phi_{4, i}=0, H_{20}: \Phi_{3, i}=0 \mid \Phi_{4, i}=0$, and $H_{10}: \Phi_{2, i}=0 \mid \Phi_{3, i}=\Phi_{4, i}=0$. The decision rule is as follows: choose a second order logistic or exponential transition function if $H_{20}$ is rejected more convincingly, and choose a first order logistic function otherwise, i.e. if either $H_{30}$ or $H_{10}$ is rejected more convincingly.

Once an appropriate model is specified, parameters of the model can be estimated by nonlinear least squares estimator. Dynamic interrelationship among the variables can be examined through the GIRFs introduced by Koop et. al. (1996) ${ }^{6}$.

\section{Data}

In this paper, we use annual data from the USA for the 1949-2016 period. Average employment level and GDP data, which are used for employment and output level, are taken from Federal Reserve Bank of St. Lois database. The index for net fixed assets as a proxy of capital stock (chain-type quantity index for net stock of fixed assets and consumer durable goods, 2009=100) is obtained from Bureau of Economic Analysis, US Department of Commerce. Energy use is total primary energy consumption (measured in quadrillion BTU) and is acquired from the US Energy Information Administration.

\section{Figure: 1}

Index of GDP, Capital Stock, Employment and Total Primary Energy Use, 1949-2012 $(1949=1000)$

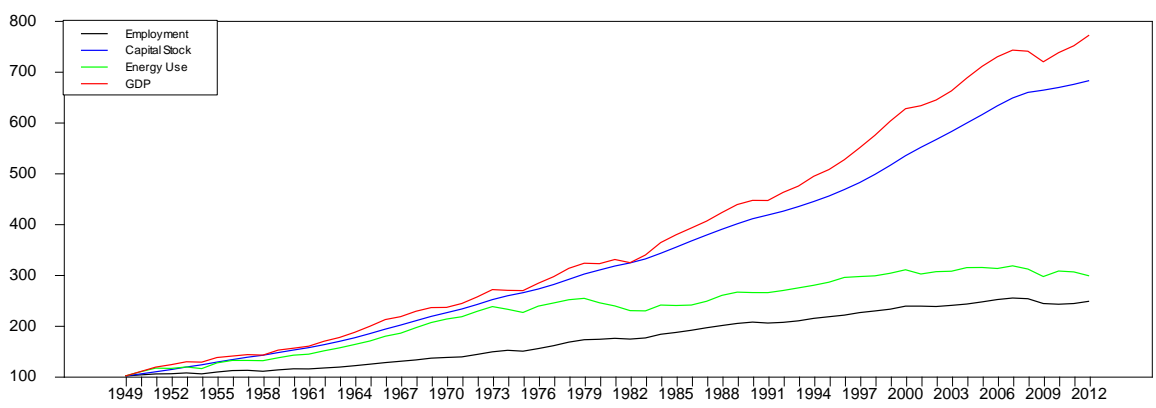

Figure 1 above plots graphs of the data used in this paper. For better comparison of the data dynamics, we plot the index of the raw data $(1949=100)$. As can be seen from the figure both output level and capital stock rose drastically during the 1949-2012 period. Note also that output grew faster than capital stock starting from early 1980s. Employment also grew steadily, albeit very slowly. Energy use, on the other hand, grew almost at the same

6 For a thorough discussion of generalized impulse response functions and comparison to traditional impulse response functions, see Chapter 2.6 in van Dijk (1999). 
rate as the capital stock till early 1970s. However, growth in energy consumption slowed down in the 1970s and increased almost at the same rate as employment since the 1980s.

We also plot per employee values of output, capital stock and energy use in Figure 2. Note that per worker energy use grew almost at the same rate as per worker output and capital stock until early 1970s. However, after reaching its maximum in 1973, per worker energy use declined through the 1970s and stayed relatively stable till 2010s. Note also that per worker output grew faster than capital stock starting from early 1980s although these two variables grew almost at the same rate until early 1970s. These dynamics suggest that growth in labor productivity has been the main driver of output growth since the 1980s. Finally, note that per worker output rose faster from the 1980s onwards when compared to the pre-1973 period $^{7}$.

Figure: 2

\section{Index of per worker GDP, Capital Stock, Total Primary Energy Use, 1949-2012 (1949=1000)}

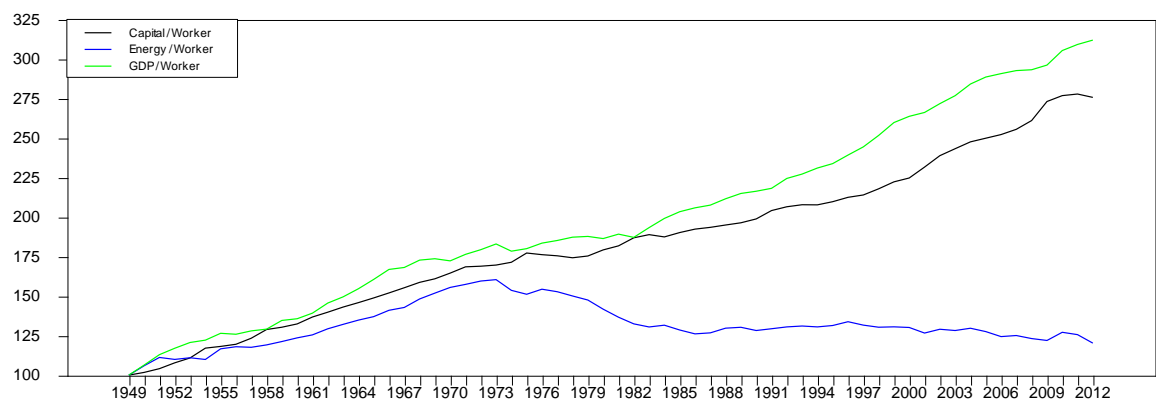

\section{The STR Model Specification and Estimation Results}

The specification procedure of a STR model starts with the specification of an appropriate linear model ${ }^{8}$. To this end, we first test stationarity and cointegration properties of data. In addition to the conventional ADF and KPSS tests, we also apply the unit root tests proposed by Leybourne et al. (1998) (LNV test) and Sollis (2004), which allow for gradual break in the deterministic trend function. The results of these tests are provided in Table 1.

In fact, we regress per worker output on constant and a time trend for the periods 1949-1973 and 1981-2012. Slope coefficient is estimated to be 1.181 and 1.456 for the first and the second periods, respectively. Full details of the estimates are available upon request. 
Table: 1

Stationarity Test Results

\begin{tabular}{clllll}
\hline & Variable & ADF test & KPSS test & LNV test & Sollis' Test \\
\hline \multirow{4}{*}{ Level } & Output & $-3,096^{* *}$ & $1,073^{* * *}$ & $-3,511$ & $-2,664$ \\
& Capital Stock & $-2,914^{* *}$ & $1,069^{* * *}$ & $-4,051$ & $-2,884$ \\
& Employment & $-1,481$ & $1,062^{* * *}$ & $-5,233$ & $-4,582$ \\
& Energy Use & $-4,061^{* * *}$ & $0,973^{* * *}$ & $-2,709$ & $-2,147$ \\
\hline \multirow{4}{*}{ First Differences } & Output & $-6,663^{* * *}$ & $0,630^{* * *}$ & $-6,100^{* * *}$ & $-5,444^{* * * *}$ \\
& Capital Stock & $-2,112$ & $0,802^{* * *}$ & $-3,763^{* * *}$ & $-3,117^{* * * *}$ \\
& Employment & $-6,284^{* * *}$ & $0,395^{*}$ & $-7,209^{* * *}$ & $-6,279^{* * * *}$ \\
& Energy Use & $-6,478^{* * *}$ & $0,783^{* * *}$ & $-7,649^{* * *}$ & $-6,646^{* * *}$ \\
\hline
\end{tabular}

Notes: *, ** and *** denote rejection of the null hypothesis of unit root for the ADF, LNV and Sollis 's tests whereas no rejection of the null hypothesis of stationarity for the KPSS test at 10\%, 5\% and 1\% significance levels, respectively.

The unit root tests provide mixed evidence about stationarity properties of the data. Taking account of the relatively low power of unit root tests in small samples, and given that one of the series might be $\mathrm{I}(0)$ whereas others are $\mathrm{I}(1)$, we apply the bounds testing approach proposed by Pesaran et al. (2001) to test for cointegration among the series, which can be used regardless of stationarity properties of the data. The bounds tests, given Table 2, imply no long-run level relationships among the variables.

Table: 2

\section{Bounds Tests for Level Relationship}

\begin{tabular}{lll}
\hline Dependent variable & Model & F test \\
\hline Output & ARDL $(1,1,2,3)$ & 2,721 \\
Capital stock & ARDL $(2,0,0,0)$ & 4,373 \\
Employment & ARDL $(4,2,3,3)$ & 3,702 \\
Energy use & ARDL $(2,1,0,0)$ & 2,836 \\
\hline Critical values & $\mathrm{I}(0)$ & $\mathrm{I}(1)$ \\
\hline $5 \%$ & 3,23 & 4,35 \\
$1 \%$ & 3,74 & 5,06 \\
\hline
\end{tabular}

Notes: The ARDL models are represented in circular order of output, capital stock, employment and energy use while the first number is the lag of the dependent variable. ${ }^{*}, *$ and $* * *$ denote rejection of the null hypothesis of no cointegration.

Since we find no cointegration relationship among output, capital, employment and energy use, we use a VAR model in first differences. The lag order of the linear VAR model is specified by applying Akaike Information Criterion (AIC). In order to test linearity of the VAR model against STR type nonlinearity, we compute the $L R$ test by using several candidates including time trend for transition variable $s_{t}$. The panel A of Table 3 shows the system-wide linearity test results. As can be seen from the table, the null hypothesis of linearity is rejected for many candidate transition variables. Nevertheless, the null hypothesis is more convincingly rejected when time trend is used. Hence, we choose time trend as the most appropriate transition variable.

In order to choose the appropriate transition function, we test the hypotheses $H_{03}$, $H_{02}$, and $H_{01}$ suggested by Teräsvirta (1994), results of which are reported in Panel B of Table 3. As $H_{01}$ is more convincingly rejected, we conclude that there is a single structural break and use a first order logistic transition function (Lin \& Teräsvirta, 1994). 
Table: 3

Linearity Test Results

\begin{tabular}{ccll}
\hline Panel A. System-wide Linearity Tests against STR-type Nonlinearity & & \\
\hline Candidate Transition Variable & & LR Test Statistic & Probability \\
\hline & $\Delta y_{t-1}$ & 78,177 & 0,00384 \\
$\Delta c_{t-1}$ & 59,013 & 0,13245 \\
$\Delta l_{t-1}$ & 58,060 & 0,15157 \\
$\Delta e_{t-1}$ & 75,367 & 0,00704 \\
Time trend & 94,039 & 0,00328 \\
\hline Panel B. Transition Function Specification Test & & 0,31554 \\
\hline$H_{03}$ & 22,470 & 0,01898 \\
$H_{02}$ & 35,216 & 0,00029 \\
\hline
\end{tabular}

After selecting both the transition variable and the transition function, we estimate the TV-VAR model using NLS estimator, whose parameter estimates are provided in Table 4.

\section{Table: 4}

The estimates of the TV-STR-VAR Model

\begin{tabular}{|c|c|c|c|c|}
\hline & Output Eqn. & Capital Eqn. & Employment Eqn. & Energy Eqn. \\
\hline Constant & $0,060(0,018)$ & $0,012(0,002)$ & $0,021(0,020)$ & $0,004(0,016)$ \\
\hline$\Delta y_{t-1}$ & $0,728(0,218)$ & $0,103(0,042)$ & $0,560(0,208)$ & $0,696(0,216)$ \\
\hline$\Delta c_{t-1}$ & $-0,821(0,589)$ & $0,693(0,079)$ & $0,215(0,586)$ & $-0,084(0,556)$ \\
\hline$\Delta l_{t-1}$ & $-0,685(0,155)$ & $-0,099(0,049)$ & $-1,191(0,334)$ & $-0,624(0,079)$ \\
\hline$\Delta e_{t-1}$ & $-0,127(0,124)$ & $-0,054(0,027)$ & $0,201(0,089)$ & $0,146(0,112)$ \\
\hline$F(t)$ & $-0,049(0,016)$ & $-0,010(0,003)$ & $-0,027(0,019)$ & $0,003(0,014)$ \\
\hline$F(t), \Delta y_{t-1}$ & $-0,112(0,285)$ & $0,089(0,055)$ & $0,166(0,370)$ & $-0,124(0,257)$ \\
\hline$F(t), \Delta c_{t-1}$ & $1,112(0,579)$ & $0,099(0,079)$ & $-0,049(0,662)$ & $-0,279(0,586)$ \\
\hline$F(t), \Delta l_{t-1}$ & $0,050(0,252)$ & $-0,033(0,057)$ & $0,349(0,559)$ & $0,609(0,202)$ \\
\hline$F(t), \Delta e_{t-1}$ & $0,217(0,184)$ & $0,039(0,034)$ & $-0,161(0,305)$ & $-0,121(0,134)$ \\
\hline Estimated Transition Function: & & \multirow{2}{*}{\multicolumn{3}{|c|}{$F(t)=(1+\exp \{-220,902(t-0,397)\})^{-1}$}} \\
\hline Residual Diagnostic Tests & & & & \\
\hline Skewness & $-0,754[0,015]$ & $-0,602[0,051]$ & $-0,626[0,042]$ & $-0,407[0,187]$ \\
\hline Kurtosis (Excess) & $0,360[0,572]$ & $0,568[0,372]$ & $1,576[0,013]$ & $0,394[0,535]$ \\
\hline J-B Normality Test & $6,611[0,037]$ & $4,870[0,088]$ & $11,143[0,003]$ & $2,247[0,325]$ \\
\hline Ljung-Box Q(1) & $0,352[0,553]$ & $0,015[0,902]$ & $2,061[0,151]$ & $0,001[0,970]$ \\
\hline $\mathrm{ARCH}(1)$ & $0,001[0,981]$ & $0,287[0,592]$ & $0,012[0,913]$ & $0,112[0,737]$ \\
\hline
\end{tabular}

Notes: Employment equation includes a dummy variable for the year 2009 for apparent outlier in that year. This dummy was included in the linear model, and hence in linearity tests as well.

Figures in parenthesis are standard errors. $J-B$ is Jarque-Berra's test for normality of residuals. Ljung-Box Q(j) denotes Ljung-Box's (1978) Q-test for residual autocorrelation of order j. ARCH(1) is Engle's (1982) LM test for first order autoregressive conditional heteroscedasticity. Figures in parenthesis are standard errors of parameter estimates. Significance levels of the diagnostic tests are provided in square brackets.

As parameter estimates convey a little information about dynamic relationship among the variables, we use GIRFs proposed by Koop et al. (1996). In order to depict how parameters of the estimated model varied over time, we plot the graph of the estimated transition function against time in Fig. 3. The figure suggests the structural change happened around 1973 and the change was rather gradual. This implies that the 1973 oil price shock has caused to changes in relationship among energy use and economic variables and is compatible with the results of the earlier studies (e.g., Moroney, 1992; Hooker, 1996). In fact, the 1973 oil shock has caused to a significant shift in production technologies and structure of the economy, evidenced with a sharp decline in energy intensity of output in most advanced countries (e.g., Stern, 2000). 
Figure: 3

Estimated Transition Function for Structural Change

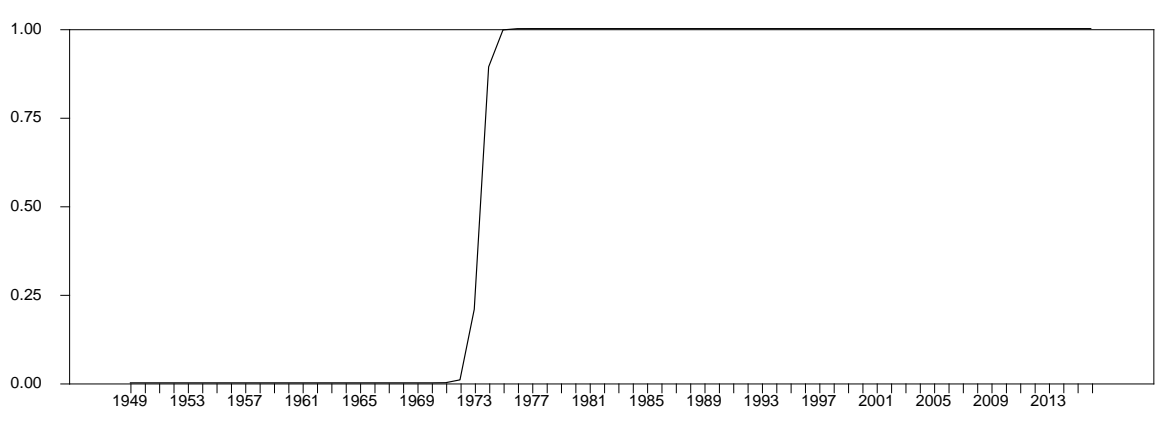

\section{Impulse Response Functions and Discussion}

We calculate the GIRFs to figure out the dynamic interactions among the variables under investigation. Since the generalized impulse responses depend on the history when the shock hits the system, we compute the GIRFs for two different time periods. The first and second sub-periods span 1949-1972 and 1977-2016 when the estimated transition function $\hat{F}(t)<0.5$ and $\hat{F}(t)>0.99$, respectively 9 .

We use all available initial data points as histories and compute impulse responses for 10 consecutive years for each sub-period. In order to see whether the dynamic effects of one of the variables on the other depends on the size or sign of the shock, we compute the impulse responses to positive and negative, small and big shocks for each sub-period ${ }^{10}$. Figs 4-6 show the responses of output, capital stock and employment to a one-time shock to the energy use. Response of energy use to shocks in output, employment and capital are shown in Figs 7-9.

9 The time period covering the years from 1973 to 1976 is not included in the computation since the transition from the first regime to the second was in progress in those years.

10 Small positive shock is set to one standard error of the residuals from the estimated TV-VAR model, whereas large shock is defined as two standard errors. Similarly, negative small and large shocks are defined as negative of one and two standard errors, respectively. The computed impulse responses to negative shocks are plotted with reversed sign and the responses to two standard error shocks are divided by two to compare them to the responses to positive shocks and one standard error shocks, respectively. 
Figure: 4

Response of Output to Energy Shocks

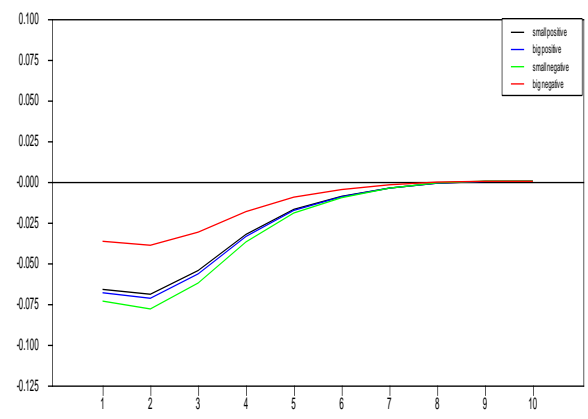

a) First sub-period before the 1973 oil shock

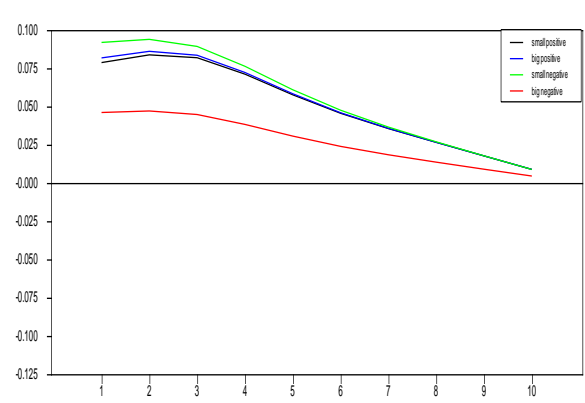

b) Second sub-period after the 1973 oil shock

Figure: 5

Response of Capital Stock to Energy Shocks

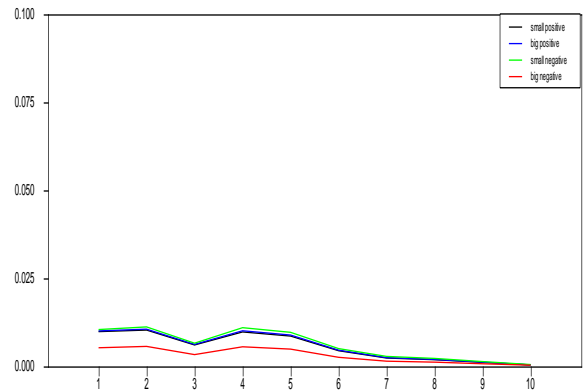

a) First sub-period before the 1973 oil shock

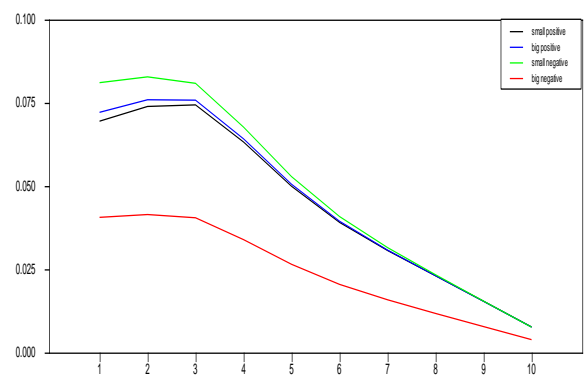

b) Second sub-period after the 1973 oil shock

Figure: 6

Response of Employment to Energy Shocks

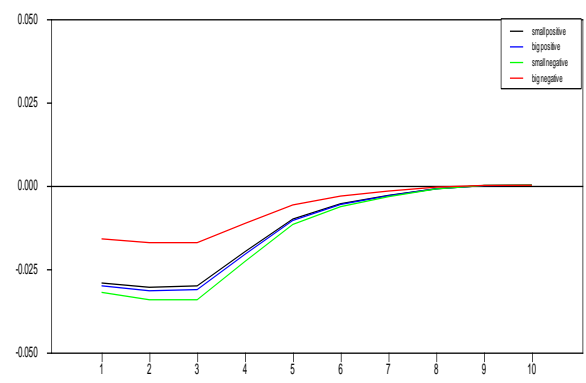

a) First sub-period before the 1973 oil shock

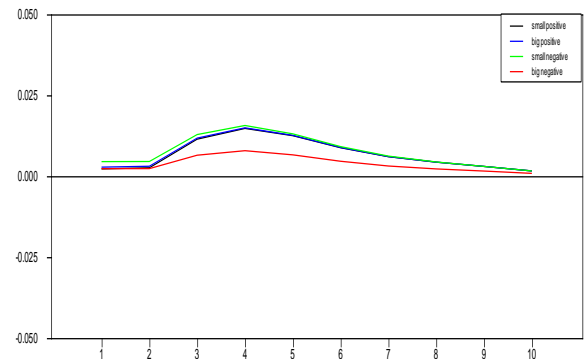

b) Second sub-period after the 1973 oil shock 


\section{Figure: 7}

\section{Response of Energy Use to Output Shocks}

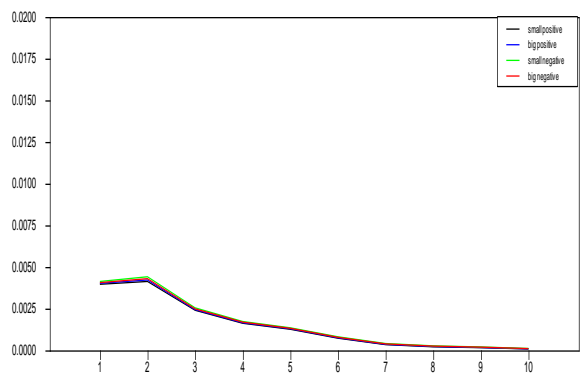

a) First sub-period before the 1973 oil shock

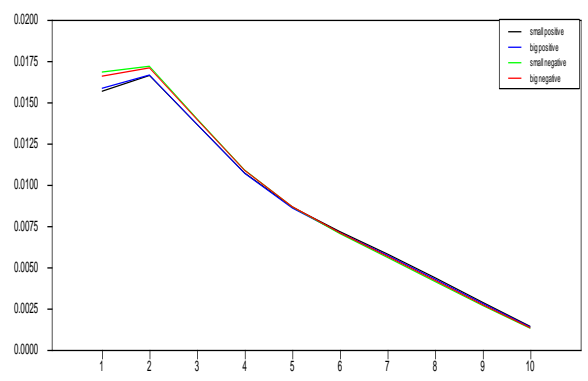

b) Second sub-period after the 1973 oil shock

Figure: 8

Response of Energy Use to Capital Shocks

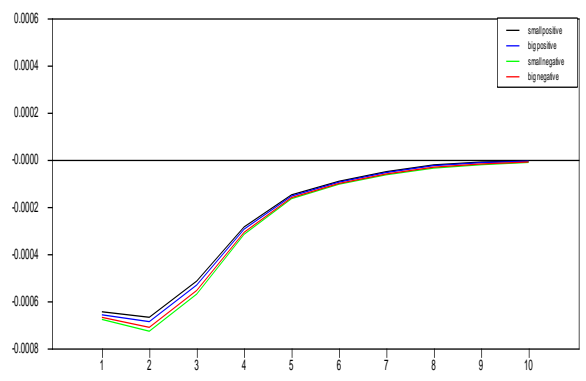

a) First sub-period before the 1973 oil shock

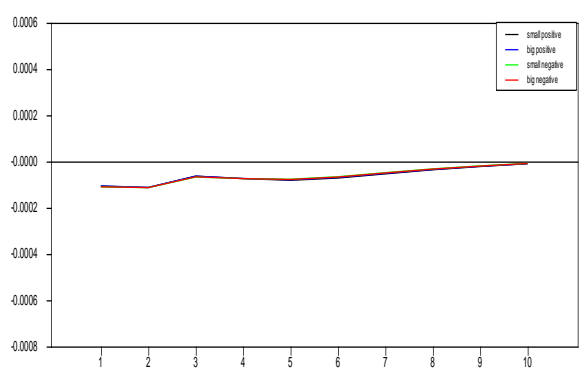

b) Second sub-period after the 1973 oil shock

\section{Figure: 9}

\section{Response of Energy Use to Employment Shocks}

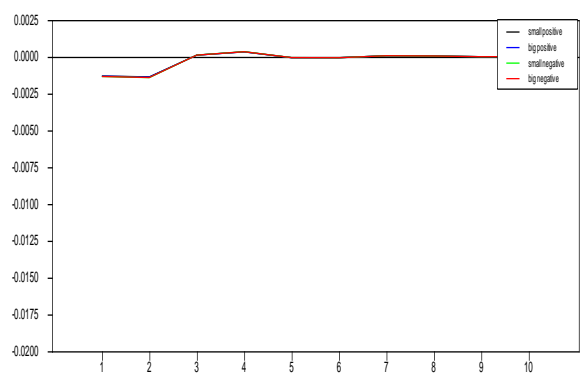

a) First sub-period before the 1973 oil shock

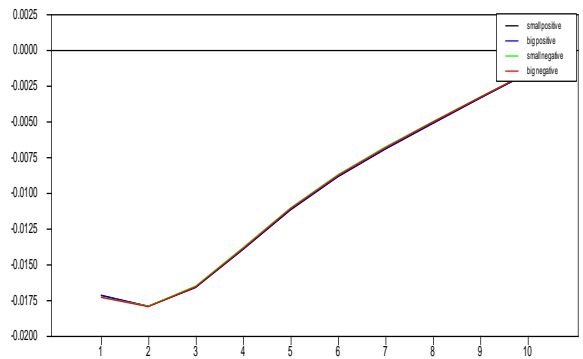

b) Second sub-period after the 1973 oil shock

The computed GIRFs reveal several interesting facts. First, as can be seen from the figures, the dynamic interrelationship among energy use and macroeconomic variables varied considerably after the 1973 oil shock. Second, the effects of energy shocks depend 
on both their sign and size. We find that negative energy shocks have greater impact when compared to positive shocks whereas the effects of small negative shocks are larger than the effects of big shocks, possibly due to the rigidities in the production process and the adjustment costs (see, for example, Ball and Mankiw, 1994). In fact, assume that energy use falls as a result of price increases. If price increase (and hence, fall in energy use) is large enough, the agents will be more willing to pay the adjustment costs and adopt new technologies to mitigate negative effects. However, if price increase (fall in energy use) is small, the adoption of new technologies will not be cost effective, and hence, this will generate relatively larger effects. Furthermore, we find no asymmetries in the response of energy to big versus small or negative versus positive shocks in either capital or labor inputs. However, negative output shocks have relatively larger effects than positive shocks on energy use.

Our results suggest that capital stock responds to energy shock positively and it has intensified in the second sub-period. While energy use affected employment negatively prior to 1973 , the direction of the effects has changed after 1973. This suggests that energyintensive industries or technologies were dominant before the 1973 oil crisis as the energy prices were relatively low. Hence, an increase in energy use might have led to substitution of labor with energy, causing to a fall in employment. However, after 1973, the sector of services has gained importance and energy saving technologies were adopted to ease the effects of the oil crisis, which might have changed the direction of the relationship. We also find that energy use falls with both capital stock and employment, the fall being amplified after 1973. Therefore, these findings imply that both employment and capital are substitutes for energy.

As regards with the relationship between output and energy use, our results suggest that energy use rises with output and this effect has been intensified after 1973. On the other hand, we find that output has fallen with energy use before 1973 but has risen after 1973 . Negative effect of energy use on output prior to 1973 contradicts to the conventional wisdom. However, as it has already been noted, an increase in energy caused to a fall in employment during this period. This result implies that the labor productivity was relatively higher than productivity of energy. In fact, relatively lower energy prices suppressed incentives to increase energy efficiency ${ }^{11}$. Furthermore, an increased energy use may have caused to a switch to inefficient production processes and/or stimulated production of energy-intensive goods with lower value added during this period. On the other hand, energy use had a positive effect on output after the 1973 oil crisis. Note also that the results imply that a positive shock to energy stimulates both capital and employment (albeit slightly). Thus, energy use increases output directly and indirectly through its effects on capital and labor use. Our results also imply that the 1973 oil shock brought about an energy-saving technological progress in the USA. This result is in line with Timmer et al. (2014). They 
argue that advanced countries have increasingly specialized in activities carried out by highskilled workers by moving capital- and energy-intensive activities towards the developing countries.

\section{Conclusions and Policy Implications}

In this study, we analyze the dynamic interrelationship between energy use and macroeconomic variables in the USA for the 1949-2016 period within the aggregate production function framework. The results of the study imply that the 1973 oil shock caused significant structural changes in the USA, and the relationship among macroeconomic variables and energy consumption has varied considerable after the oil shock. We also find that the responses of economic variables to energy shocks depend not only on the sign, but also on the size of the shocks.

Our results have clear policy implications. First, we find that energy use and employment are substitutes, suggesting that the energy saving policies will not harm employment. However, these policies may suppress economic growth in the short to the medium run. Second, we find that big negative energy shocks have relatively low adverse effects on output growth, implying that aggressive energy saving policies might be more politically viable compared to conservative ones. For example, if relatively high carbon taxes are imposed, the producers are likely to incur adjustment costs and adapt energyefficient production processes. Third, our results indicate that energy-conserving policies must be supported by other policies. In fact, we find that increasing labor and capital reduce energy use. Therefore, the policies promoting capital accumulation and employment as well as adoption of energy-saving production technologies can also help reducing energy use, hence, greenhouse-gas emission. Fourth, our results suggest that increasing income leads to more energy use. This finding implies that the demand for energy will rise further with growing income, pointing to the importance of the policies aimed at ensuring energy security. Finally, the results of the paper reveal rather complex and time-varying interaction among energy, production factors and output. This implies that one must take account of these complexities in examination of dynamic interactions of economic variables. In addition, it is well established that both the energy mix and sectoral composition of output vary considerably in many countries over time, mainly being driven by the changes in technology and the consumer preferences. Therefore, time-varying and asymmetric interaction among energy use and output across various sectors of economy as well as by different energy sources must be further examined in order to better comprehend the overall change in the relationship among energy use and output. Examining such complex interactions will further our knowledge of these relationships and will aid the design of more appropriate energy policies. This task is left for the future research.

\section{References}

Apergis, N. \& J.E. Payne (2009), "Energy consumption and economic growth in Central America: evidence from a panel cointegration and error correction model", Energy Economics, 31, 211-216. 
Araç, A. \& M. Hasanov (2014), "Asymmetries in the dynamic interrelationship between energy consumption and economic growth: Evidence from Turkey", Energy Economics, 44, 259-269.

Aslan, A.N. \& N. Apergis \& S. Yildirim (2014), "Causality between energy consumption and GDP in the US: evidence from wavelet analysis", Frontiers in Energy, 8(1), 1-8.

Bai, J. \& P. Perron (1998), "Estimating and testing linear models with multiple structural changes", Econometrica, 66(1), 47-78.

Ball, L. \& N.G. Mankiw (1994), “Asymmetric price adjustment and economic fluctuations”, The Economic Journal, 104, 247-61.

Bartleet, M. \& R. Gounder (2010), "Energy consumption and economic growth in New Zealand: results of trivariate and multivariate models", Energy Policy, 38, 3508-17.

Beaudreau, B.C. (2005), "Engineering and economic growth", Structural Change and Economic Dynamics, 16, 211-220.

Berndt, E.R. \& D.O. Wood (1979), "Engineering and econometric interpreta-tions of energy-capital complementarity", American Economic Review, 69(3), 342-354.

Bowden, N. \& J.E. Payne (2010), "Sectoral analysis of the causal relationship between renewable and non-renewable energy consumption and real output in the US", Energy Sources Part B: Econ Plan Policy, 5, 400-8.

BP (British Petroleum) (2016), Statistical Review of World Energy, June 2016, $<$ https://www.bp.com/content/dam/bp/pdf/energy-economics/statistical-review-2016/bpstatistical-review-of-world-energy-2016-full-report.pdf>, 25.04.2018.

Carmona, M. \& J. Feria \& A.A. Golpe \& J. Iglesias (2017), "Energy consumption in the US reconsidered. Evidence across sources and economic sectors", Renewable and Sustainable Energy Reviews, 77, 1055-1068.

Engle, R.F. (1982), “Autoregressive conditional heteroscedasticity with estimates of the variance of United Kingdom inflation”, Econometrica, 50(4), 987-1007.

Fiorito, G. \& J.C.J.M. van den Bergh (2011), "Capital-Energy Substitution for Climate and Peak Oil Solutions? An International Comparison Using the EU-KLEMS Database”, Working Paper ICTA-UAB.

Ghali, K.H. \& M.I.T. El-Sakka (2004), "Energy use and output growth in Canada: a multivariate cointegration analysis", Energy Economics, 26(2), 225-238.

Granger, C.W.J. \& T. Teräsvirta (1993), Modelling Nonlinear Economic Relationships, Advanced Texts in Econometrics: Oxford University Press.

Gross, C. (2012), "Explaining the (non-) causality between energy and economic growth in the U.S.a multivariate sectoral analysis", Energy Econ, 34, 489-99.

Hall, C.A.S. \& C.J. Cleveland \& R.K. Kaufmann (1986), Energy and Resource Quality: The Ecology of the Economic Process, New York: Wiley-Interscience.

Hamilton, J.D. (2003), "What is an oil shock?”, Journal of Econometrics, 113, 363-398.

Hasanov, M. \& E. Telatar (2011), “A re-examination of stationarity of energy consumption: evidence from new unit root tests", Energy Policy, 39(12), 7726-7738.

Hasanov, M. \& A. Arac \& F. Telatar (2010), "Nonlinearity and structural stability in the Phillips curve: evidence from Turkey", Economic Modelling, 27, 1103-1115.

Hooker, M.A. (1996), "What happened to the oil price-macroeconomy relationship?", Journal of Monetary Economics, 38, 195-213. 
Jorgenson, D.W. (1984), “The role of energy in productivity growth”, The Energy Journal, 5(3), 11 26.

Koetse, M.J. \& H.L.F. De Groot \& R. Florax (2008), "Capital-energy substitutionand shifts in factor demand: a meta-analysis", Energy Economics, 30, 2236-2251.

Koop, G. \& M.H. Pesaran \& S.M. Potter (1996), "Impulse response analysis in nonlinear multivariate models", Journal of Econometrics, 74, 119-147.

Kraft, J. \& A. Kraft (1978), “On the relationship between energy and GNP”, Journal of Energy and Development, 3, 401-403.

Lee, C.C. \& C.P. Chang (2008), "Energy consumption and economic growth in Asian economies: A more comprehensive analysis using panel data", Resource and Energy Economics, 3, 5065 .

Leybourne, S. \& P. Newbold \& D. Vougas (1998), "Unit roots and smooth transitions", Journal of Time Series Analysis, 19, 83-97.

Ljung, G.M. \& G.E.P. Box (1978), "On a measure of a lack of fit in time series models”, Biometrika, 65(2), 297-303.

Lin, C.F.J. \& T. Teräsvirta (1994), "Testing the constancy of regression parameters against continuous structural change", Journal of Econometrics, 62(2), 211-228.

Lundbergh, S. \& T. Teräsvirta \& D. van Dijk (2003), "Time-varying smooth transition autoregressive models", Journal of Business \& Economic Statistics, 21(1), 104-121.

Lutkepohl, H. (1982), "Non-causality due to omitted variables", Journal of Econometrics, 19, $367-$ 378.

Luukkonen, R. \& P. Saikkonen \& T. Teräsvirta (1988), "Testing linearity against smooth transition autoregressive models", Biometrika, 75, 491-99.

Menyah, K. \& Y. Wolde-Rufael (2015), "Electricity consumption and economic growth in transition countries: a revisit using bootstrap panel Granger causality analysis", Energy Econ, 44, 325-30.

Moroney, J.R. (1992), "Energy, capital and technological change in the United States", Resour. Energy, 14, 363-380.

Oh, W. \& K. Lee (2004), "Causal relationship between energy consumption and GDP: the case of Korea 1970-1999”, Energy Economics, 26(1), 51-59.

Omri, A. (2014), “An international literature survey on energy-economic growth nexus: Evidence from country-specific studies", Renew Sustain Energy Rev, 38, 951-959.

Ozturk, I. (2010), “A literature survey on energy-growth nexus”, Energy Policy, 38, 340-349.

Payne, J.E. (2009), "On the dynamics of energy consumption and output in the US", Appl Energy, $86(4), 575-7$.

Payne, J.E. (2010), "Survey of the international evidence on the causal relationship between energy consumption and growth", Journal of Economic Studies, 37(1), 53-95.

Payne, J.E. (2011), “On biomass energy consumption and real output in the US", Energy Sources Part B: Econ Plan Policy, 6, 47-52.

Pesaran, M.H. \& Y. Shin \& R.J. Smith (2001), "Bounds Testing Approaches to the Analysis of Level Relationships", Journal of Applied Econometrics, 16, 289-326.

Rahman, S. \& A. Serletis (2010), "The asymmetric effects of oil price and monetary policy shocks: a nonlinear VAR approach", Energy Economics, 32, 1460-1466. 
Sari, R. \& B.T. Ewing \& U. Soytas (2008), "The relationship between disaggregate energy consumption and industrial production in the United States: an ARDL approach", Energy Econ, 30(5), 2302-13.

Smyth, R. \& P.K. Narayan (2015), “Applied econometrics and implications for energy economics research", Energy Economics, 50, 351-358.

Sollis, R. (2004), "Asymmetric adjustment and smooth transitions: a combination of some unit root tests", Journal of Time Series Analysis, 25, 409-417.

Stern, D.I. (1993), "Energy and economic growth in the USA: a multivariate approach", Energy Economics, 15(2), 137-150.

Stern, D.I. (2000), "A multivariate cointegration analysis of the role of energy in the US macroeconomy", Energy Economics, 22, 267-283.

Teräsvirta, T. \& H.M. Anderson (1992), "Characterizing nonlinearities in business cycles using smooth transition autoregressive models", Journal of Applied Econometrics, 7, 119-136.

Teräsvirta, T. (1994), "Specification, estimation, and evaluation of smooth transition autoregressive models", Journal of the American Statistical Association, 89, 208-218.

Timmer, M.P. \& A.A. Erumban \& B. Los \& R. Stehrer \& G.J. de Vries (2014), "Slicing up Global Value Chains", Journal of Economic Perspectives, 28(2), 99-118.

Tiwari, A.K. (2014), "The asymmetric Granger-causality analysis between energy consumption and income in the United States", Renewable and Sustainable Energy Reviews, 36, 362-369.

van Dijk, D. (1999), Smooth Transition Models: Extensions and Outlier Robust Inference, Tinbergen Institute Research Series, no. 200.

Wang, Y. \& Y. Wang \& J. Zhou \& X. Zhu \& G. Lu (2011), "Energy consumption and economic growth in China: A Multivariate causality test", Energy Policy, 39, 4399-406.

Yu, E.S.H. \& J.C. Jin (1992), "Cointegration tests of energy consumption, income, and employment”, Resources and Energy, 14(3), 259-266.

Zachariadis, T. (2007), "Exploring the relationship between energy use and economic growth with bivariate models: new evidence from G-7 countries", Energy Economics, 29(6), 12331253.

Zhixin, Z. \& R. Xin (2011), "Causal relationships between energy consumption and economic growth", Energy Procedia, 5, 2065-71. 